Article

\title{
Coastal Peloids as Geological Heritage: Evidence from the Taman Peninsula (Southwestern Russia)
}

\author{
Yury A. Fedorov ${ }^{1}$, Dmitry N. Gar'kusha ${ }^{1}$, Roman G. Trubnik ${ }^{1}$, Natalia A. Latushko ${ }^{2}$ and \\ Dmitry A. Ruban ${ }^{3, *(D)}$ \\ 1 Department of Physical Geography, Ecology, and Nature Protection, Institute of Earth Sciences, \\ Southern Federal University, Zorge Street 40, Rostov-on-Don 344090, Russia; fed29@mail.ru (Y.A.F.); \\ gardim1@yandex.ru (D.N.G.); truroman@sfedu.ru (R.G.T.) \\ 2 Department of Economic Sociology and Regional Governance, Institute of Sociology and Regional Studies, \\ Southern Federal University, Pushkinskaja Street 160, Rostov-on-Don 344022, Russia; nlatushko@yandex.ru \\ 3 Department of Business in Hospitality Sphere, Higher School of Business, Southern Federal University, \\ 23-ja linija Street 43, Rostov-on-Don 344019, Russia \\ * Correspondence: ruban-d@mail.ru
}

Received: 3 May 2019; Accepted: 27 May 2019; Published: 29 May 2019

\begin{abstract}
The coastal peloidis a peculiar and poorly-studied geological substance. Peloids occurin the Bugaz, Kiziltash, and Vityazevolimans and the Chemburka Lake on the southern coast of the Taman Peninsula. The studied peloids are dark-colored mud enriched in hydrogen sulfide and methane and constitute the uppermost $10-20 \mathrm{~cm}$ of bottom sediments. Being geologically unique, the coastal peloids of the Taman Peninsula can be recognized as ageoheritage site. Their uniqueness is linked to sediment type, biogeochemical processes, economic value, and depositional environment. The most typical peloids are found in the BugazLiman and the Chemburka Lake, proposed as geosites. The recognized coastal geoheritage site can be used for the purposes of science, education, and tourism, and its utility seems to be especially high because of its close location to the big resort area of Anapa. It appears to be important to balance management of this geoheritagesite with peloid extraction for balneological purposes. The studied coastal muds should be involved into the regional planning programs aimed at sustainable development (international experience and, particularly, some examples from the British coasts should be taken into consideration). Particularly, it is necessary to put peloid use into the context of regional planning and sustainable natural resource management.
\end{abstract}

Keywords: coastal heritage; geochemical processes; geotourism; lakes; peloid; regional planning; southwestern Russia

\section{Introduction}

The coastal zones of seas and oceans are highly-dynamic environments where various geological and geomorphological processes, such as those linked to wave and wind activity, sediment discharge, rich ecosystem growth, anthropogenic pressure, interact. Therefore, it is not surprising that coasts host numerous pieces of the world-class geological heritage (geoheritage), representing either very typical (almost textbook-looking) or, in contrast, highly-specific geological and geomorphological features of undisputable uniqueness. This issue was addressed by Brocx and Semeniuk [1] and was demonstrated with representative examples from the United Kingdom (southern coasts) [2,3], Australia (western coast) [4], Canada (Bonavista Peninsula) [5], and Egypt (Mediterranean coast to the west of Alexandria) [6]. The Jurassic Coast World Heritage Site is among the most famous coastal sites with world-class geoheritage [3]. However, the spectrum of coast-related geoheritage features and their world distribution are yet to be fully understood, and the relevant investigations remain on agenda. 
Peloid, known commonly as "therapeutic mud",is ahighly-specific, geological substance comprising mineral, organic, water, and gas components [7-9]. Essentially, these are highly-specific types of sediments with peculiar geochemical properties and are often organic-rich. These have been used widely over the past two centuries for medical, cosmetic, and recreational purposes $[8,9]$. However, their potential as geoheritagesites is yet to be recognized. Peloids occur in different geological settings (e.g., lacustrine and volcanic settings), and, particularly, these are quite common in the coastal zones of seas. However, coastal peloids have been studied rarely, e.g., a few examples have been reported from the Azov Sea [10] and the Adriatic Sea [11]. In the Russian South (a vast territory between the Don River in the north, the Azov Sea in the west, the Caspian Sea in the east, and the Caucasus Mountains in the south), peloids have been described from various geological settings, chiefly continental [7,12,13], but the knowledge of their coastal typeremains restricted [14,15]. The geoheritage importance of this peloidtype has been never analyzed.

The objective of the present study is the firstassessment of the geoheritage potential of peloids distributed along the southern (Black Sea) coast of the Taman Peninsula in southwestern Russia. Attention is paid to both the geological (e.g., the thickness of mud layers and basic geochemical proxies) and the geoheritage properties of the bottom muds found in several coastal lakes. These properties permit judgments of uniqueness of these coastal sediments and their relevance to geological, biogeochemical, and geomorphological aspects of coastal zone dynamics.

\section{Study Territory}

The study territory corresponds to the southern coast of the Taman Peninsula in southwestern Russia (Figure 1). This large ( 2000 km²) peninsula divides the Azov Sea in the north from the Black Sea in the south. This is the westernmost edge of the Greater Caucasus domain, although lacking mountains. A part of this geological structure was formed as a result of sediment accumulation near the mouth of the Kuban River and an active mud volcanism.

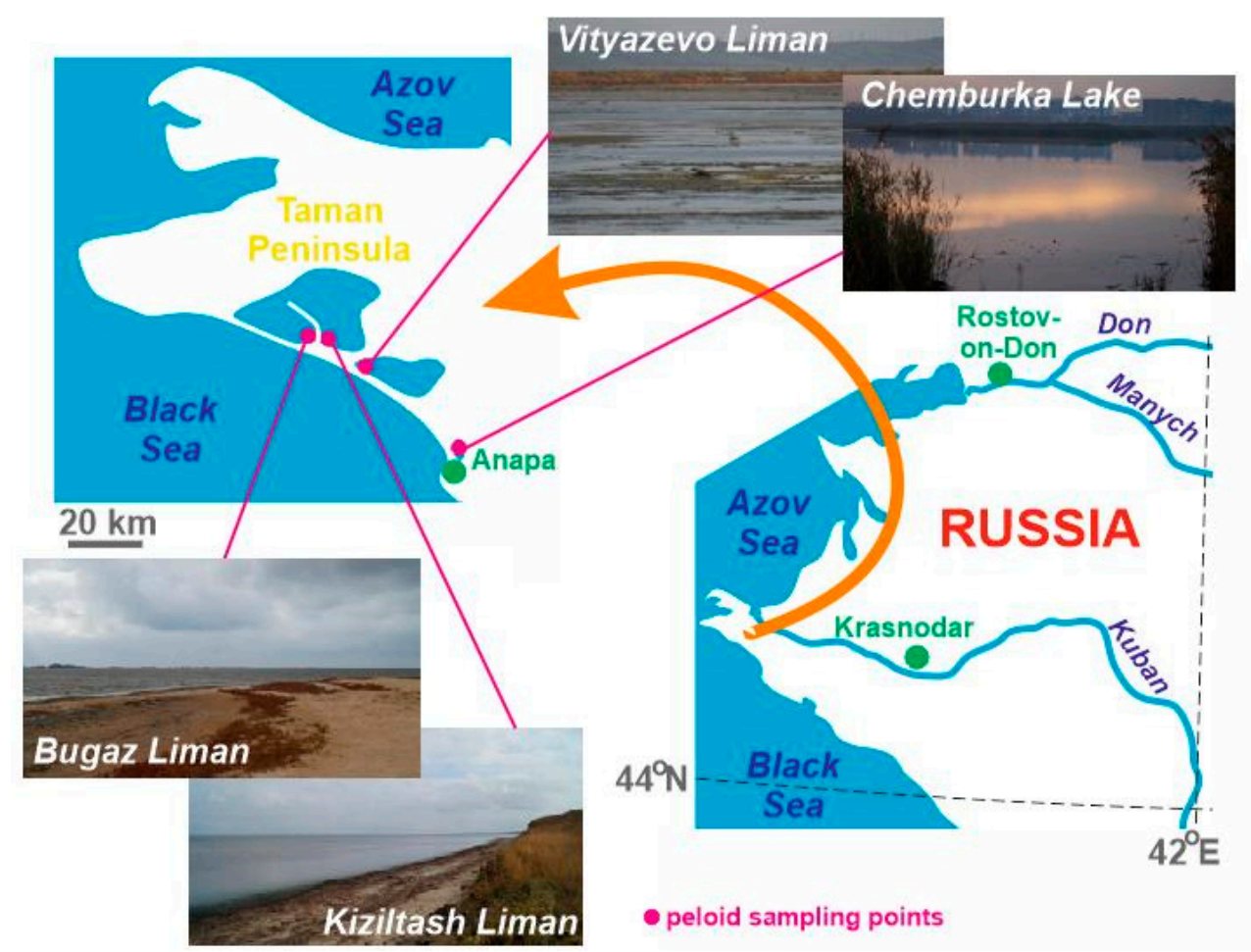

Figure 1. Location of the studied water objects of the Taman Peninsula coastal zone.

The southern (Black Sea) coast of the peninsula is characterized by the presence of large lakes called 'limans'. These lakes were formed as a result of sea flooding of the former river valleys or 
topographic lows of coastal plains and separation of these water bodies by accumulation barriers. Limans share some characteristics with estuaries and lagoons, which may retain some hydrological connection to the sea, and their environment resembles coastal wetlands (even swamps). The main water objects of the study territory are the BugazLiman $\left(35 \mathrm{~km}^{2}\right)$, the KiziltashLiman $\left(137 \mathrm{~km}^{2}\right)$, the VityazevoLiman $\left(64 \mathrm{~km}^{2}\right)$, and the Chemburka Lake $\left(\sim 1 \mathrm{~km}^{2}\right)$ (Figure 1).

\section{Materials and Methods}

This study is fully based on the materials collected during field investigations of the noted water objects located on the southern coast of the Taman Peninsula. The Bugaz, Kiziltash, and Vityazevolimans and the Chemburka Lake were visited and described. Bottom sediments were sampled with the GOIN core pipe to the depth of $25 \mathrm{~cm}$. Samples for analyses were taken with the interval of $5 \mathrm{~cm}$. Peloids usually occur within the interval of $0-20 \mathrm{~cm}$, and, thus, the depth of $25 \mathrm{~cm}$ marks full transition to the typical lake silt/sand underlying peloids. The very typical properties of the peloids are registered in their upper layers, and this is why additional sampling point marks the depth of $2 \mathrm{~cm}$. All samples were transported and analyzed in a laboratory in the standard way at the Hydrochemical Institute (Rostov-on-Don) in order to document four principal geochemical proxies of peloids, namely $\mathrm{Eh}, \mathrm{pH}$, methane content in wet mass (natural state), and total hydrogen sulfide content in wet mass (natural state). The analytical procedure is the same as in the works of Fedorov and Ruban [12] and Fedorov et al. [14,16]. Particularly, theEkotest 2000 ionometer was used for Eh and $\mathrm{pH}$ measurements, and the total hydrogen sulfide content was established bya photometric approach with dimethylparaphenylendiamine. Some preliminary results of geochemical studies of the coastal peloids of the Taman Peninsula [15] are considered in the present analysis.

This work focuses on the recognition of geoheritagesites linked to coastal peloids. Generally, geoheritage is the entity of unique geological phenomena occurring globally, nationally, regionally, or locally. The conceptual framework of the modern geoheritage studies and the principles/methods of its description are given in the works of Brilha [17], Brocx and Semeniuk [18], Coratza et al. [19], Gordon [20], Gray [21], Habibi et al. [22], Henriques and Brilha [23], Henriques et al. [24], Ibáñez et al. [25], Mikhailenko and Ruban [26,27], Prosser [28], Prosser et al. [29], Reynard and Brilha [30], Reynard et al. [31], Ruban [32], and Wimbledon [33]. The approaches employed earlier for the purposes of peloid-related geoheritage characteristics [12,34] have to be noted.

Visits to the Bugaz, Kiziltash, and Vityazevolimans and the Chemburka Lake included their field description with regard to potentially unique features. In this study, the uniqueness of peloids of the four above-mentioned water bodies is argued on the basis of judgments of their rarity. The latter can be evaluated qualitatively in regards to geological knowledge about peloid properties and origin on the studied and other territories. The uniqueness is higher in the cases where distribution of peloids with the given properties is restricted in space. The principal geological (also geochemical) characteristics of the studied peloids permit to distinguish their main features, each of which can be attributed to any geoheritage type. The classification of "geoheritage", proposed by Habibi et al. [22], is employed for this purpose; the types include stratigraphical, palaeontological, sedimentary, geochemical, and hydrological ( 20 in total). Undoubtedly, some features are of bigger or smaller geoheritage value, which is taken into account. This relative importance is also linked to the uniqueness of these features, as well as to their importance to site integrity. The next procedure is the selection of geoheritage sites (geosites). Geosites are manifestations of unique geological phenomena that require proper conservation and can be used for the purposes of geoscience, geoeducation, and/or geotourism. Geositesestablished in this study are ranked as local, regional, national, or global. The rank depends on the uniqueness of the principal features, i.e., their rarity. The main anthropogenic factors affecting the state of the selected geositeson the study territoryare identified based on field observations and previous research results [15].

Recognition of geosites is necessary forseveral reasons. First, geoheritage distribution should be understood well, and, as peloids differ in properties, only sites with the most characteristic properties 
are useful as geoheritage sites. Second, geosites are necessary to facilitate local conservation of geoheritage sites and planning of the study of territory development (geosite recognition permit focusing on main geoheritage "points"). Third, geosites should be chosen properly in order to promote them as tourist attractions and to be included in geoeducational and geotourism excursions.

\section{Results}

The analyzed coastal peloids of the Taman Peninsula are quite similar, although certain differences between the four water objects are also found. The general view of peloids is shownin Figure 2, and the principal geochemical proxies are summarized in Table 1. Brief characteristics of the bottom deposits of the Bugaz, Kiziltash, and Vityazevolimans and the Chemburka Lake are given below.

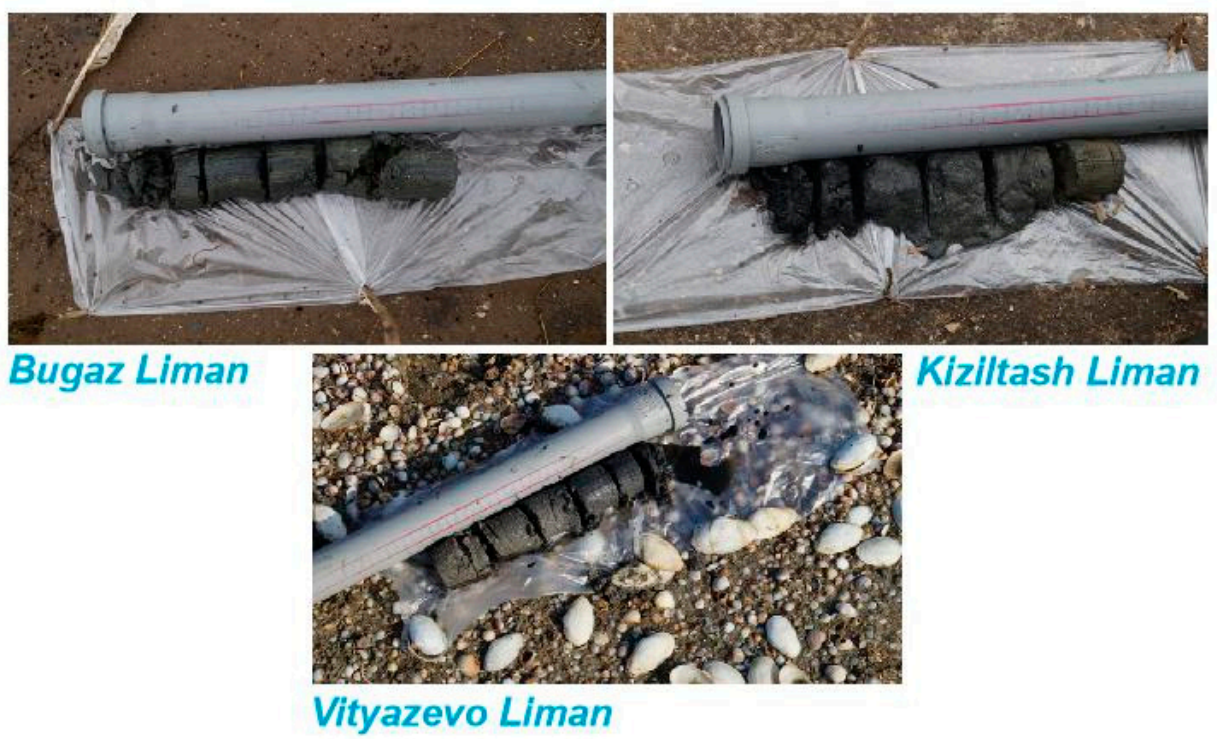

Figure 2. Samples of the studied coastal peloids of the Taman Peninsula.

The peloids of the BugazLiman form the upper $(0-20 \mathrm{~cm})$ layer of the bottom sediments. In the interval of $0-5 \mathrm{~cm}$, these are black mud with half-degraded plant remains with an evident smell of hydrogen sulfide (Figure 2). In the underlying horizons, the mud turns to be grey and the smell is not noticeable. In the lowest part, mollusk shells are found. Geochemical peculiarities include hydrogen sulfide enrichment, in the intervals of $0-5$ and $10-15 \mathrm{~cm}$, and significant methane content in the uppermost horizon of the peloids (Table 1). In the KiziltashLiman, the peloids form the bottom layer with a thickness of $10 \mathrm{~cm}$. The mud is dark-grey with some amount of sand particles, plant debris, and a weak smell of hydrogen sulfide (Figure 2). A very high content of hydrogen sulfide is restricted to the upper $2 \mathrm{~cm}$ (Table 1). The peloids of the VityazevoLiman form the bottom layer with a thickness of no more than $10 \mathrm{~cm}$. These are dark-grey muds with a significant amount of sand particles and mollusk shells (Figure 2). Below, the sediment is represented by greyish sand with clay and mollusk shells. The content of hydrogen sulfide is significant in the interval of 0-15 cm, and it peaks at the depth of $0-5 \mathrm{~cm}$ (Table 1). Finally, the Chemburka Lake is characterized by a relatively thick $(20 \mathrm{~cm})$ layer of peloids, which looks like dark-grey mud with strong smell of hydrogen sulfide. The color becomes black at the depth of 10-20 cm. At the same interval, half-degraded plant debrisis abundant. The contents of methane and hydrogen sulfide are high within the entire profile (Table 1).

It should be noted that the principal geochemical proxies (Eh, $\mathrm{pH}$, methane content, and total hydrogen sulfide content) of peloidsboast by values (Table 1) that generally match the national standards of "therapeutic muds", i.e., these peloids can be used for the purpose of recreation (balneology) [15]. Generally, the descriptions given above imply that the specific peloid properties are exceptionally 
well-manifested in the Chemburka Lake and are a bit less well-manifested in the BugazLiman; these are less evident in the KiziltashLiman, and especially in the VityazevoLiman.

Table 1. Principal geochemical proxies of the studied peloids (adapted from [15]).

\begin{tabular}{|c|c|c|c|c|}
\hline Depth, cm & $\mathrm{Eh}, \mathrm{mV}$ & $\mathrm{pH}$ & $\begin{array}{c}\mathrm{CH}_{4}, \mu \mathrm{g} / \mathrm{g} \\
\text { (Wet Mass) }\end{array}$ & $\begin{array}{c}\sum \mathrm{H}_{2} \mathrm{~S}, \mathrm{mg} / \mathrm{g} \\
\text { (Wet Mass) }\end{array}$ \\
\hline \multicolumn{5}{|c|}{ BugazLiman } \\
\hline $0-2$ & -76.5 & 7.76 & 0.13 & 0.35 \\
\hline $2-5$ & -62.6 & 8.04 & 0.07 & 0.37 \\
\hline 5-10 & -104.7 & 7.83 & 0.02 & 0.12 \\
\hline $10-15$ & -198.0 & 7.60 & 0.03 & 0.27 \\
\hline $15-20$ & -101.0 & 7.51 & 0.03 & 0.19 \\
\hline $20-25$ & -125.0 & 7.59 & 0.03 & 0.16 \\
\hline \multicolumn{5}{|c|}{ KiziltashLiman } \\
\hline $0-2$ & -68.5 & 7.46 & 0.03 & 1.44 \\
\hline $2-5$ & -54.5 & 7.48 & 0.02 & 0.22 \\
\hline $5-10$ & -59.8 & 7.61 & 0.04 & 0.23 \\
\hline $10-15$ & -59.8 & 7.57 & 0.02 & 0.10 \\
\hline $15-20$ & -76.0 & 7.61 & 0.02 & 0.20 \\
\hline $20-25$ & -85.5 & 7.56 & 0.04 & 0.01 \\
\hline \multicolumn{5}{|c|}{ VityazevoLiman } \\
\hline $0-2$ & -84.8 & 7.56 & 0.01 & 0.57 \\
\hline $2-5$ & -67.0 & 7.54 & 0.02 & 0.50 \\
\hline $5-10$ & -84.6 & 7.69 & 0.01 & 0.27 \\
\hline $10-15$ & -49.5 & 7.60 & 0.01 & 0.35 \\
\hline $15-20$ & -33.7 & 7.75 & 0.01 & 0.07 \\
\hline $20-25$ & -2.5 & 7.33 & 0.01 & 0.01 \\
\hline \multicolumn{5}{|c|}{ Chemburka Lake } \\
\hline $0-2$ & +46.0 & 7.51 & 22.0 & 1.12 \\
\hline $2-5$ & -25.0 & 7.64 & 6.01 & 1.16 \\
\hline $5-10$ & -79.0 & 7.59 & 11.6 & 1.11 \\
\hline $10-15$ & -19.5 & 7.47 & 13.2 & 1.56 \\
\hline $15-20$ & -11.5 & 7.55 & 9.78 & 0.64 \\
\hline $20-25$ & -3.0 & 7.64 & 7.63 & 0.69 \\
\hline
\end{tabular}

The studied coastal peloids of the Taman Peninsula seem to be really a unique geological phenomenon, owing to their characteristics that showthat these peloids are peculiar geological substances distinguished by their physical views and geochemical properties. The origin of these peloids, explained by Fedorov et al. [15], is linked to hydrogen sulfide formation and methane generation (the latter is especially intense in the Chemburka Lake) due to activity of microbial communities on the bottom of water objects. The changes in the methane and hydrogen sulfide contents occur along the sampled profiles, more or less synchronously with the changes in Eh and pH (Table 1). This observation confirms the idea of dependence of methane and hydrogen sulfide generation on lake-bottom environment and sediment properties [15]. It should be noted that it was the dynamics of the coastal zone that triggered the very formation of these lakes and their partial isolation from the 
sea. Additionally, discharge of highly-contaminated waste water to the water objects (especially in the case of the Chemburka Lake, located on the important resort area of Anapa) facilitates modern peloid formation [15]. Peloids with such characteristics and origin seem to be unusual geological substances relative to typical sediments of the coastal zone, dominated commonly by gravels, sands, or silts. Spatially, their uniqueness is limited only to southwestern Russia where such substances seem to be rare. Somewhat similarpeloids are known in the other regions, although are rarely described comprehensively: For instance, limans with more or less comparable bottom sediments, are quite common along the coasts of the Azov, Black, and Adriatic seas [10,35]. However, the Black Sea to Azov Sea region, which is the most characteristic for liman development, and the southern coast of the Taman Peninsula provide outstanding examples of such water objects and the relevant peloids. In the other words, the geoheritage potential of the studied coastal peloids results from both their specific and typical features.

Peloidsare a complex geological substance, and, thus, they possess several unique features (Table 2). Essentially, the bottom mud is a peculiar sediment, and, consequently, the sedimentary geoheritage type seems to be most important. The origin of this sediment is linked strongly to highly-complex biogeochemical processes on the bottom of limans and coastal lakes [15], and, therefore, the mud represents a unique geochemical phenomenon. The latter is a bit less important because geochemical processes can be documented in the course of special investigations, and, thus, these processes remain 'invisible' (in the terms of [27]). The occurrence that the studied peloids (especially those of the BugazLiman and the Chemburka Lake) can be used in local spa centersmakes this geological substance unique (rare coastal deposits have such significance). However, the presence of the bigger resources of so-called 'therapeutic mud' in the Russian South (e.g., [7]) decreases the relative importance of the economical type of the Taman Peninsula geoheritage. Finally, the Bugaz, Kiziltash, and Vityazevolimans and the Chemburka Lake provide examples of the geological activity of lakes (a highly-specific lacustrine depositional environment allowing peloid formation), which is relevant to the hydrological type of geoheritage.

Table 2. Unique features of the studied peloids.

\begin{tabular}{ccc}
\hline Geoheritage Type & Relevant Features & Relative Importance \\
\hline Sedimentary & Mud as a peculiar sediment & Very high \\
\hline Geochemical & Biogeochemical peculiarities and ongoing processes & High \\
\hline Economical & $\begin{array}{c}\text { Mud as an economically-valuable resource for local } \\
\text { recreation industry ('therapeutic mud') }\end{array}$ & Moderate \\
\hline Hydrological & Lake as mud depositional environment & Low \\
\hline
\end{tabular}

The only recognition of the peloids of the southern coast of the Taman Peninsula as a kind of geoheritage site is not enough. Locations where this geoheritagesite can be observed and studied have to be specified. To attribute all four water objects considered in this study to one big geosite is not sensible because these occur on significant territory, stretching along the coastline for $\sim 50 \mathrm{~km}$ (Figure 1). If so, the only possible solution is to designate each studied water object as a separate geosite. However, the characteristics of the peloids presented above imply clearly that the specific peloid properties are best manifested in the Chemburka Lake and the BugazLiman. In these cases, the peloid layer of bottom deposits is relatively thick and the content of hydrogen sulfide is high. Therefore, both noted water objects should be considered as geosites. It is impossible to make a choice between them because their characteristics reflect differences in peloid accumulation and maturation (e.g., strikingly-different content of methane (Table 1)). The proposed geosites should both be ranked nationally because they represent geological phenomena that are rare when considering the size of Russia. Speculation about global rank is not possible at this stage because of the very limited knowledge of coastal peloids in other parts of the world. If further investigations show that peloids similar to those established on the southern coast of the Taman Peninsula are really rare in the world, the rank will turn to be global. 
Significant anthropogenic stress is registered at the Chemburka Lake geosite, contaminated with waste water from the nearby recreational and agricultural areas. Although waste water influxunbalances the hydrochemical regime, the same influx facilitates methane production on the lake bottom [15], which makes the local peloid properties specific. In other words, this kind of anthropogenic stress contributes to the uniqueness of the geosites.

\section{Discussion}

Geoheritage is a significant geological resource for exploitation for the purposes of science, education, and tourism $[21,27,32]$. Scientific importance of the coastal peloidgeoheritage of the Taman Peninsula is undisputable. Despite some preliminary research $[14,15]$ (and this study), the geological knowledge of their properties and origin are still limited. For instance, much attention should be paid to the clay component of the bottom sediment. Geological studies of other types of peloids have revealed that clay mineralogy and provenance are of crucial importance for correct understanding of the mechanism of this sediment formation [36-38]. Educational importance of the studied peloids is limited, partly due tothe high complexity of the processes of their formation. However, professionally-guided excursions of students ofgeosciences and medicine can be directed to the proposed geosites(especially because of the geosite high rank-see above) in order to demonstrate the natural state of 'therapeutic mud'. Such students are quite numerous in the universities of the Russian South, located in Rostov-on-Don, Krasnodar, etc. Moreover, some universities have recreational camps and educational testsites along the Black Sea coast, which can become startpoints for educational excursions. Finally, the importance of tourism at the studied peloid sites appears to be recognizable because natural balneological resources are interesting to the broad spectrum of visitors and comprehension of these resources requires some knowledge (at least, elementary) of their geological context. Most importantly, the study territory can be located closely to the country-scale resort area of Anapa, attracting hundreds of thousands of visitors each summer (these visitors represent the entire Russian society and usually aim at simple beach recreation, although many are interested in spending their time being active). The demand for local tourism programs and excursions is unprecedentedly high in this resort area. The Chemburka Lake geosite is located directly in this resort area, and, thus, it is most suitable to be involved in the local tourism development.

Peloidsthat represent geological resources can be exploited in multiple ways. On the one hand, they can be extracted for distance use (e.g., for medical purposes). In this case, theycould be a typical mineral resource. On the other hand, the value of peloids is linked to their geological uniqueness, which allows insitu exploitation for the purposes of science, education, and tourism (see above) and also requires proper conservation. The entire peloidgeoheritage and the two proposed geosites occur on a vast coastal territory. Geoheritage conservation would conflict with peloid exploitation for recreation purposes. Consequently, water objects with peloids should become subjects of regional planning. The relevant concept for this is shown in Figure 3. At the first stage of planning, it is suggested that the local geoheritage is recognized and that the recreation resource quality of the coastal peloids is assessed. These tasks can be solved simultaneously because geoheritage analysis requires examination of the basic balneological properties of peloids. Moreover, the higher the balneological potential, the higher the value of the economical geoheritage type of the peloids (this is because the economical importance of any geological resource increases its general value, including its heritage value [39-41]). At the next stage of planning, it is possible to designate geosites (in Russia, there is a good legislative basis to achieve this task) and to confirm their protected status. The present work demonstrates that the geoheritage site recognition permits finding the properties that make aproper geosite selection possible. However, geopark creation does not appear to be feasible for two reasons. On the one hand, the diversity of unique geological features is not high. On the other hand, the territory is partly of outstanding importance for beach recreation and the relevant infrastructure development. As for the recreational (balneological) resource, development of a program of its extraction for use in spa centers and medical institutions is required. Peloids are a renewable resource [7], and this program 
should prescribe permitted volumes of extraction and a degree of anthropogenic intervention to allow extraction, at the same speed as the new portions of peloids form on the bottom of water objects. Further investigations of the coastal peloids of the study territory will allowa calculation of the rate of their formation, and this information will help to define the noted permitted volumes of extraction. Undoubtedly, at this stage, the needs of geoheritage conservation and peloid extraction should be balanced. If extraction is not excessive, it is not a factor of danger to the geoheritage.

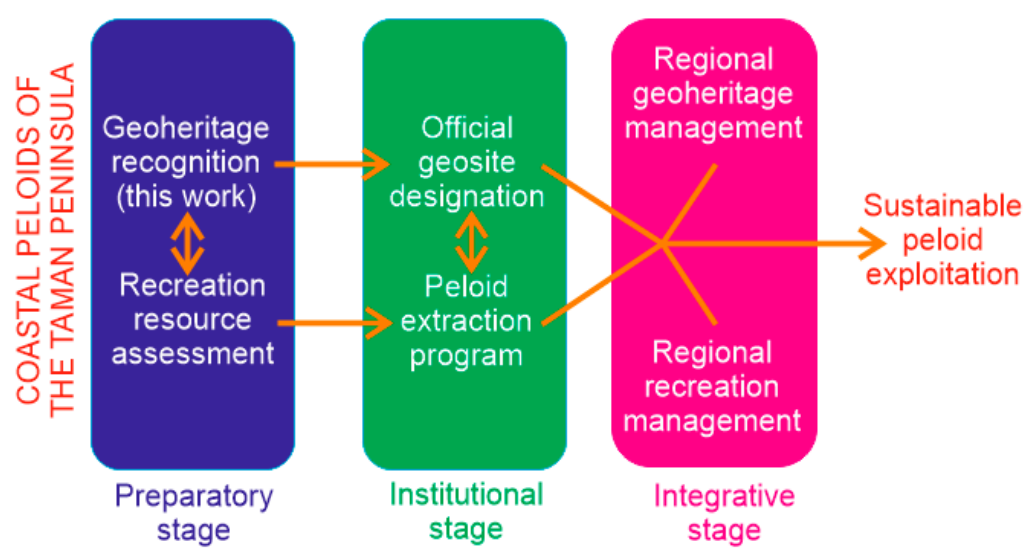

Figure 3. Strategy of the coastal peloid use.

The third stage of planning is putting the coastal peloids into the broader contexts (Figure 3). On the one hand, the Taman Peninsula boasts by diverse geoheritage. The most promising and globally-important features of the Taman Peninsula are mud volcanoes [42,43] and representative sections of the Miocene deposits [44]. If so, the coastal geosites should be managed together with the other geosites of the peninsula. On the other hand, peloids(not only those described in this paper) constitute a significant, economically-valuable resource for the entire Russian South [7]. This resource has been partly exploited already and it forms a substantial basis for the functioning of several big spa centers located in the Krasnodar and Stavropol regions of the Russian Federation. The rational exploitation of the coastal peloids of the Taman Peninsula should take into account the needs of the regional balneological industry and the demand for its products and services. Finding mutual benefits between the regional geoheritage and recreation management should contribute to sustainable peloid exploitation.

The planning of the peloid-related geoheritage management on the southern coast of the Taman Peninsula can be compared to the coastal geoheritage management in some world-famous geotourism destinations. The best examples can be found on the coasts of Great Britain [2,3]. Although thegeoheritage of the British coasts (stratigraphy, fossils, sedimentary rocks, etc.) differs essentially from that of the Taman Peninsula (peloids), both territories boast a significant development of their recreation industry, anthropogenic press, and their high value of unique geological features. If so, management plans implemented at the Jurassic Coast World Heritage Site and strategies aimed there at finding balance between conservation and exploitation of geoheritage [3] can be taken into consideration for the purposes of regional planning in the coastal zone of the Taman Peninsula. The only serious difference between the Jurassic Coast World Heritage Site and the Taman Peninsula is that the issues of local administration, local community cooperation and negotiations (in relation to management of natural resources), have not been studied deeply in the Russian South. Filling this gap is an important subject for further study.

\section{Conclusions}

The investigation undertaken of the coastal peloids of the Taman Peninsula permits the making of some general conclusions. The studied coastal peloids are geological formations, which looklike dark-colored mudand form the upper layer $(10-20 \mathrm{~cm})$ of the bottom deposits of the Bugaz, Kiziltash, 
and Vityazevolimans and the Chemburka Lake. Their origin is linked to the formation of hydrogen sulfideand methane generation by microbial communities. These peloids can be recognized as a highly-specific geoheritage, the features of which belong to sedimentary, geochemical, economical, and hydrological geoheritagetypes. Based on the results obtained from their analysis, two geositeshave been proposed, namely the BugazLiman and the Chemburka Lake. The investigatedpeloids can be used for the purposes of science, education, and tourism. In particular, balneological purposesrequirea rational extraction (at the same speed in which new peloid portions form)of the context of the regional geoheritagesite and its recreation management.

The present study emphasizes the heritage value of peculiar geological and geomorphological objects and processes in coastal zones. Although much attention has been paid to coastal erosion, accumulation forms, and cliff exposures, some other, highly-specific phenomena can be registered, for example, the formation ofpeloids. This is essentially a highly-complex geological process, the uniqueness of which extends the vision of the geodiversity of coastal zones. Further investigations should be aimed at geological studies and geoheritage inventories of coastal peloids in the other regions of the world, including the coasts of the Black, Azov, Caspian, and Mediterranean seas.

Author Contributions: Conceptualization, Y.A.F. and D.A.R.; field investigations, Y.A.F., D.N.G. and R.G.T.; methodology, Y.A.F., R.G.T. and D.A.R.; interpretation, Y.A.F., N.A.L. and D.A.R.; writing, D.A.R.

Funding: This research was supported by the grant of the Russian Science Foundation Project 17-17-01229.

Acknowledgments: The Guest Editor, F. Rizzetto (Italy), is thanked for her kind invitationto contribute to this special issue and useful recommendations, and the anonymous reviewers are thanked for their support and precious suggestions.

Conflicts of Interest: The authors declare no conflict of interest.

\section{References}

1. Brocx, M.; Semeniuk, V. Coastal geoheritage: Encompassing physical, chemical, and biological processes, landforms, and other geological features in the coastal zone. J. R. Soc. Western Aust. 2009, 92, 243-260.

2. Brunsden, D. The Dorset and East Devon Coast World Heritage Site: A Vision. Proc. Geol. Assoc. 2019, in press. [CrossRef]

3. Cochrane, J. Tourism, Partnership and a Bunch of Old Fossils: Management for Tourism at the Jurassic Coast World Heritage Site. J. Heritage Tourism 2008, 2, 156-167. [CrossRef]

4. Brocx, M.; Semeniuk, V. Coastal geoheritage: A hierarchical approach to classifying coastal types as a basis for identifying geodiversity and sites of significance in Western Australia. J. R. Soc. Western Aust. 2010, 93, 81-113.

5. McCallum, A.; O'Brien, S. Geotourism and the coastal geological heritage of the Bonavista peninsula: Current challenges and future opportunities. Geosci. Can. 2012, 39, 6-7.

6. El-Asmar, H.M.; Ahmed, M.H.; Taha, M.M.N.; Assal, E.M. Human Impacts on Geological and Cultural Heritage in the Coastal Zone West of Alexandria to Al-Alamein, Egypt. Geoheritage 2012, 4, $263-274$. [CrossRef]

7. Fedorov, Y.A.; Ruban, D.A. Peloids as important resource for regional sustainable development: Conceptual considerations. Espacios 2018, 3951, 21.

8. Gomes, C.; Carretero, M.I.; Pozo, M.; Maraver, F.; Canista, P.; Armijo, F.; Legido, J.L.; Teixeira, F.; Rautureau, M.; Delgado, R. Peloids and pelotherapy: Historical evolution, classification, and glossary. Appl. Clay Sci. 2013, 75-76, 28-38. [CrossRef]

9. Munteanu, C.; Dumistrascu, M. Therapeutic muds. Balneo-Res. J. 2011, 2, 12-16. [CrossRef]

10. Solonenko, A.N. Composition of organic matters and enzymatic activity of peloids of hyperhaline water bodies of the north-western coast of the Sea of Azov (Ukraine). Hydrobiol. J. 2015, 51, 22-27. [CrossRef]

11. Mihelčić, G.; Kniewald, G.; Ivanišević, G.; Čepelak, R.; Mihelčić, V.; Vdović, N. Physico-chemical characteristics of the peloid mud from Morinje Bay (eastern Adriatic coast, Croatia): Suitability for use in balneotherapy. Environ. Geochem. Health 2012, 34, 191-198. [CrossRef]

12. Fedorov, Y.A.; Ruban, D.A. Geoheritage Resource of Small Mud Lakes in the Semi-Arid Environments of the Russian South. Resources 2019, 8, 75. [CrossRef] 
13. Sallam, E.S.; Abd El-Aal, A.K.; Fedorov, Y.A.; Bobrysheva, O.R.; Ruban, D.A. Geological heritage as a new kind of natural resource in the Siwa Oasis, Egypt: The first assessment, comparison to the Russian South, and sustainable development issues. J. Afr. Earth Sci. 2018, 144, 151-160. [CrossRef]

14. Fedorov, Y.A.; Nikolayevich, G.D.; Trubnik, R.G. Bacteria of the Clostridium genus, methane and hydrogen sulfide in sulfide mud of the Taman Peninsula reservoirs. Online J. Biol. Sci. 2018, 18, 315-322. [CrossRef]

15. Fedorov, Y.A.; Gar'kusha, D.N.; Potapov, E.G.; Trubnik, R.G. GazovyjsostavpeloidovTamanskogopoluostrova (Gas composition of the peloids of the Taman Peninsula). Kurortnajameditsina 2017, 3, 26-33. (In Russian)

16. Fedorov, Y.A.; Nikanorov, A.M.; Tambieva, N.S. The first data on the distribution of biogenous methane content in water and bottom sediments of Lake Baikal. DokladyAkademiiNauk 1997, 353, 394-397.

17. Brilha, J. Inventory and Quantitative Assessment of Geosites and Geodiversity Sites: A Review. Geoheritage 2016, 8, 119-134. [CrossRef]

18. Brocx, M.; Semeniuk, V. The '8Gs'-A blueprint for Geoheritage, Geoconservation, Geo-education and Geotourism. Aust. J. Earth Sci. 2019, in press. [CrossRef]

19. Coratza, P.; Reynard, E.; Zwolinski, Z. Geodiversity and Geoheritage: Crossing Disciplines and Approaches. Geoheritage 2018, 10, 525-526. [CrossRef]

20. Gordon, J.E. Geoheritage, geotourism and the cultural landscape: Enhancing the visitor experience and promoting geoconservation. Geosciences 2018, 8, 136. [CrossRef]

21. Gray, M. Geodiversity: Valuing and Conserving Abiotic Nature; Wiley-Blackwell: Chichester, UK, 2013; pp. 1-495.

22. Habibi, T.; Ponedelnik, A.A.; Yashalova, N.N.; Ruban, D.A. Urban geoheritage complexity: Evidence of a unique natural resource from Shiraz city in Iran. Resour. Policy 2018, 59, 85-94. [CrossRef]

23. Henriques, M.H.; Brilha, J. UNESCO Global Geoparks: A strategy towards global understanding and sustainability. Episodes 2017, 40, 349-355. [CrossRef]

24. Henriques, M.H.; Pena dos Reis, R.; Brilha, J.; Mota, T. Geoconservation as an Emerging Geoscience. Geoheritage 2011, 3, 117-128. [CrossRef]

25. Ibáñez, J.-J.; Brevik, E.C.; Cerdà, A. Geodiversity and geoheritage: Detecting scientific and geographic biases and gaps through a bibliometric study. Sci. Total Environ. 2019, 659, 1032-1044. [CrossRef]

26. Mikhailenko, A.V.; Ruban, D.A. Geoheritage in Deltaic Environments: Classification Notes, Case Example, and Geopark Implication. Environments 2019, 6, 18. [CrossRef]

27. Mikhailenko, A.V.; Ruban, D.A. Geo-Heritage Specific Visibility as an Important Parameter in Geo-Tourism Resource Evaluation. Geosciences 2019, 9, 146. [CrossRef]

28. Prosser, C.D. Our rich and varied geoconservation portfolio: The foundation for the future. Proc. Geol. Assoc. 2013, 124, 568-580. [CrossRef]

29. Prosser, C.; Murphy, M.; Larwood, J. Geological Conservation: AGuide to Good Practice; Natural England: Peterborough, UK, 2006; pp. 1-145.

30. Reynard, E. Geoheritage: Assessment, Protection, and Management; Brilha, J., Ed.; Elsevier: Amsterdam, The Netherland, 2018; pp. 1-482.

31. Reynard, E.; Perret, A.; Bussard, J.; Grangier, L.; Martin, S. Integrated Approach for the Inventory and Management of Geomorphological Heritage at the Regional Scale. Geoheritage 2016, 8, 43-60. [CrossRef]

32. Ruban, D.A. Geodiversity as a precious national resource: A note on the role of geoparks. Resour. Policy 2017, 53, 103-108. [CrossRef]

33. Wimbledon, W.A.P. Geoheritage in Europe and its conservation. Episodes 2013, 36, 68.

34. Rocha, F.; Ferreira da Silva, E. Geotourism, Medical Geology and local development: Cape Verde case study. J. Afr. Earth Sci. 2014, 99, 735-742. [CrossRef]

35. Shuisky, Y.D.; Pano, N. The results of the investigation of nearshore lakes of the Adriatic and Black seas. Period. Biologorum 2000, 102, 457-468.

36. Barhoumi, T.; Bekri-Abbes, I.; Srasra, E. Physicochemical characteristics and suitability of curative pastes made of Tunisian clay minerals and thermal waters for use in pelotherapy. C. R. Chim. 2019, 22, 126-131. [CrossRef]

37. Carretero, M.I.; Pozo, M.; Legido, J.L.; Fernández-González, M.V.; Delgao, R.; Gómez, I.; Armijo, F.; Maraver, F. Assessment of three Spanish clays for their use in pelotherapy. Appl. Clay Sci. 2014, 99, 131-143. [CrossRef]

38. Gomes, C.S.F. Healing and edible clays: A review of basic concepts, benefits and risks. Environ. Geochem. Health 2018, 40, 1739-1765. [CrossRef] 
39. Molchanova, T.K.; Ruban, D.A. New Evidence of the BangestanGeoheritage Resource in Iran: Beyond Hydrocarbon Reserves. Resources 2019, 8, 35. [CrossRef]

40. Price, W.R.; Ronck, C.L. Gushing about black gold: Oil and natural gas tourism in Texas. J. Heritage Tourism 2018, 13, 440-454. [CrossRef]

41. Ruban, D.A.; Tiess, G.; Sallam, E.S.; Ponedelnik, A.A.; Yashalova, N.N. Combined mineral and geoheritage resources related to kaolin, phosphate, and cement production in Egypt: Conceptualization, assessment, and policy implications. Sustain. Environ. Res. 2018, 28, 454-461. [CrossRef]

42. Bujakaite, M.I.; Lavrushin, V.Y.; Pokrovsky, B.G.; Kikvadze, O.E.; Polyak, B.G. Strontium and oxygen isotopic systems in waters of mud volcanoes of the Taman Peninsula. Lithol. Min. Resour. 2014, 49, 47-54. [CrossRef]

43. Ovsyuchenko, A.N.; Sobisevich, A.L.; Sysolin, A.I. On the relationship between recent tectonic processes and mud volcanism by the example of Mt. Karabetov, Taman Peninsula. Izv. Phys. Solid Earth 2017, 53, 606-617. [CrossRef]

44. Popov, S.V.; Rostovtseva, Y.V.; Fillippova, N.Y.; Golovina, L.A.; Radionova, E.P.; Goncharova, I.A.; Vernyhorova, Y.V.; Dykan, N.I.; Pinchuk, T.N.; Iljina, L.B.; et al. Paleontology and stratigraphy of the Middle-Upper Miocene of the Taman Peninsula: Part 1. Description of key sections and benthic fossil groups. Paleontol. J. 2016, 50, 1039-1206. [CrossRef]

(C) 2019 by the authors. Licensee MDPI, Basel, Switzerland. This article is an open access article distributed under the terms and conditions of the Creative Commons Attribution (CC BY) license (http://creativecommons.org/licenses/by/4.0/). 